\title{
Protective effect of Mucuna pruriens against arsenic-induced liver and kidney dysfunction and neurobehavioral alterations in rats
}

\author{
Preethi Concessao ${ }^{1}$, Laxminarayana Kurady Bairy² and Archana Parampalli Raghavendra ${ }^{1}$
}

1. Department of Physiology, Melaka Manipal Medical College, Manipal Academy of Higher Education, Manipal, Karnataka, India; 2. Department of Pharmacology, RAK College of Medical Sciences, RAK Medical and Health Sciences University, Ras Al Khaimah, United Arab Emirates.

Corresponding author: Preethi Concessao, e-mail: preethi.concessao@manipal.edu

Co-authors: LKB: klbairy@gmail.com, APR: archana.h@manipal.edu

Received: 08-01-2020, Accepted: 21-05-2020, Published online: 12-08-2020

doi: www.doi.org/10.14202/vetworld.2020.1555-1566 How to cite this article: Concessao P, Bairy LK, Raghavendra AP (2020) Protective effect of Mucuna pruriens against arsenic-induced liver and kidney dysfunction and neurobehavioral alterations in rats, Veterinary World, 13(8): 1555-1566.

\begin{abstract}
Background and Aim: Intoxication of arsenic in rats is known to result in neurological effects as well as liver and kidney dysfunction. Mucuna pruriens has been identified for its medicinal properties. The aim of the study was to investigate the protective effect of aqueous seed extract of $M$. pruriens on sodium arsenite-induced memory impairment, liver, and kidney functions in rats.

Materials and Methods: The experiment was divided into short-term treatment (45 days) and long-term treatment ( 90 days), with each group divided into nine sub-groups consisting of six animals each. Sub-groups 1 and 2 served as normal, and $\mathrm{N}$-acetylcysteine (NAC) controls, respectively. Sub-groups 3-9 received sodium arsenite in drinking water (50 mg/L). In addition, sub-group 4 received NAC $(210 \mathrm{mg} / \mathrm{kg}$ b.wt) orally once daily, sub-groups 5-7 received aqueous seed extract of M. pruriens (350 mg/kg b.wt, $530 \mathrm{mg} / \mathrm{kg} \mathrm{b.wt,} \mathrm{and} 700 \mathrm{mg} / \mathrm{kg} \mathrm{b.wt)} \mathrm{orally} \mathrm{once} \mathrm{daily} \mathrm{and} \mathrm{sub-groups} 8$ and 9 received a combination of NAC and aqueous seed extract of $M$. pruriens $(350 \mathrm{mg} / \mathrm{kg} \mathrm{b.wt} \mathrm{and} 530 \mathrm{mg} / \mathrm{kg}$ b.wt) orally once daily. Following the treatment, the blood was drawn retro-orbitally to assess the liver (serum alanine transaminase [ALT], serum aspartate transaminase, and serum alkaline phosphatase) and kidney (serum urea and serum creatinine) functions. Learning and memory were assessed by passive avoidance test. Animals were sacrificed by an overdose of ketamine, and their Nissl stained hippocampal sections were analyzed for alterations in neural cell numbers in CA1 and CA3 regions.
\end{abstract}

Results: In the short-term treatment, groups administered with M. pruriens $530 \mathrm{mg} / \mathrm{kg}$ b.wt alone and combination of NAC + M. pruriens $350 \mathrm{mg} / \mathrm{kg}$ b.wt exhibited a significant improvement in memory retention, less severe neurodegeneration, and decrease in serum ALT levels. In long-term treatment, groups administered with $M$. pruriens $700 \mathrm{mg} / \mathrm{kg}$ b.wt alone and combination of $\mathrm{NAC}+M$. pruriens $350 \mathrm{mg} / \mathrm{kg}$ b.wt, respectively, showed better memory retention, decreased neural deficits, and reduced levels of kidney and liver enzymes.

Conclusion: The seed extract of $M$. pruriens showed significant enhancement in memory and learning. The number of surviving neurons in the CA1 and CA3 regions also increased on treatment with M. pruriens. Serum ALT, serum urea, and serum creatinine levels showed significant improvement on long-term treatment with M. pruriens.

Keywords: hippocampus, kidney functions, liver functions, memory and learning, Mucuna pruriens, sodium arsenite.

\section{Introduction}

Arsenic is enormously present in underground water throughout the world [1]. The permissible limit for arsenic in drinking water is $10 \mathrm{ppb}$ (WHO) [2]. Abdominal pain, severe diarrhea and vomiting are few symptoms of acute arsenic toxicity $[3,4]$. Chronic ingestion of arsenic results in its accumulation in vital organs, causing atherosclerosis, hypertension, and peripheral nerve damage [5,6]. Exposure to arsenic affects cognitive function [7-11]. It weakens the cytoskeleton structure, thus damaging the axon $[12,13]$. Arsenic binds with sulfhydryl groups, producing

Copyright: Concessao, et al. Open Access. This article is distributed under the terms of the Creative Commons Attribution 4.0 International License (http://creativecommons.org/licenses/ by/4.0/), which permits unrestricted use, distribution, and reproduction in any medium, provided you give appropriate credit to the original author(s) and the source, provide a link to the Creative Commons license, and indicate if changes were made. The Creative Commons Public Domain Dedication waiver (http:// creativecommons.org/publicdomain/zero/1.0/) applies to the data made available in this article, unless otherwise stated. reactive oxygen species (ROS) resulting in the death of the cell exposed to it $[14,15]$. It passes through the blood-brain barrier and accrues in the brain $[16,17]$. Learning and memory decline in humans and animals indicate that the hippocampus is more prone to toxicity caused by arsenic $[18,19]$. Liver and kidneys are also prone to toxicity since they are essential in metabolic and excretory processes, respectively. It is to be noted that the absorption of arsenic primarily takes place in the small intestine, following which it is found in various organs, including the liver [20-23]. The involvement of the liver is a complication of long-term exposure to arsenic since it tends to get accumulated with repeated exposure [24]. Various studies have shown a connection between continuous exposure to arsenic and liver disease in addition to liver fibrosis, liver cirrhosis, and hepatomegaly [25-30]. Transformation of arsenic from its pentavalent to less soluble and toxic trivalent form occurs in the kidneys. Sites prone to damage are capillaries, glomeruli, and tubules [28-31]. Epidemiological 
analysis and animal studies have revealed that mild and persistent arsenic exposure causes kidney damage and increase the risk of cancer [32,33]. Further, studies in experimental animals and humans have described that exposure to inorganic arsenic causes damage to the kidney resulting in loss of brush border, tubular necrosis, and renal failure [32,34].

N-Acetylcysteine (NAC), a precursor to glutathione, acts as a biological antioxidant and is used in the treatment of arsenic poisoning [35]. Tissue injury in various organs is prevented due to its ability to scavenge oxygen free radicals $[35,36]$. The antioxidant property is due to the presence of sulfhydryl group $[37,38]$.

At present, herbal drugs have gained clinical importance since synthetic drugs have shown increased side effects. Antioxidants of plant origin with free-radical scavenging properties could have great importance as therapeutic agents in several diseases caused due to oxidative stress. Mucuna pruriens is a leguminous plant which has an anti-lipid peroxidation, anthelmintic, anti-inflammatory, and aphrodisiac and neuroprotective properties [39-42]. In a study done by Sampath et al., [43], it was reported that the neuroprotective property of M. pruriens was due to antioxidant activity. A study confirmed that $M$. pruriens could ameliorate kidney damage, which is one of the complications of diabetes mellitus, indicating the nephroprotective property of seed extract [44]. It is also established that the seeds of $M$. pruriens lowered blood urea and creatinine in rats [45]. Further studies have found that hydroethanolic extract of $M$. pruriens demonstrated hepatoprotective activity against anti-tubercular drugs and alcohol models [46]. One of the biggest advantages of plant extracts is that they are less expensive to produce and are affordable to the poor population who need them the most. However, the protective role of $M$. pruriens in arsenic-induced liver and kidney functions, together with neurobehavioral alteration, is not much studied.

Based on the antioxidant and nutritional properties of $M$. pruriens, an attempt was made to investigate the protective effect of aqueous seed extract of $M$. pruriens on sodium arsenite-induced memory impairment as well as liver, and kidney functions in rats.

\section{Materials and Methods}

\section{Ethical approval}

All procedures used in this study were approved by the Animal Ethics Committee of Manipal Academy of Higher Education. (IAEC/KMC/52/2015).

\section{Study period and location}

This study was conducted from September 2018 to March 2019 at Animal House of Manipal Academy of Higher Education and at the Laboratory of Melaka Manipal Medical College, Manipal.

\section{Chemicals}

Sodium arsenite A.R (98.5\%) was obtained from Nice Chemicals (P) Ltd, Cochin, India. NAC (Samarth Life Sciences Private Limited, India) was procured from a medical store at Udupi. Thiobarbituric acid, trichloroacetic acid, and DTNB were obtained from Durga Laboratories, Mangalore and the standard kits for liver and kidney function tests were procured from Hitech Biomedicals, Mangalore, India.

\section{Preparation of plant extract}

The identification of $M$. pruriens seeds was carried out by the Faculty of Pharmacognosy (Specimen No: SDM/954/17112301). Seeds of M. pruriens were collected locally, cleaned, and ground into a fine powder. $50 \mathrm{~g}$ of this powder was macerated in $100 \mathrm{ml}$ distilled water for 1 day at $4^{\circ} \mathrm{C}$. Centrifugation of this suspension was carried out at $10000 \times g$ for $25 \mathrm{~min}$. The supernatant was lyophilized to powder and was stored at $-4^{\circ} \mathrm{C}$ and prepared freshly for use [47]. The yield from the extract was $15.8 \mathrm{~g}$.

\section{Experimental animals}

The experimental animals consisted of 108 nos. of male rats (9-12 weeks old) locally bred in the animal house. They were housed in cages with appropriate bedding, standard temperature $\left(22-24^{\circ} \mathrm{C}\right)$, light-dark cycle (12 h-12 h), and relative air humidity (40-60\%). Rats were acclimated to the laboratory conditions for 7 days before the commencement of the experiment, which was maintained according to the guidelines of CPCSEA, Government of India, for the use of laboratory animals. During the course of the experiment, rats were fed with laboratory feed and water.

\section{Experimental design}

The experiment was divided into short-term treatment ( 45 days) and long-term treatment (90 days), with each group divided into nine subgroups consisting of six animals each. Subgroups 1 and 2 served as normal and NAC controls, respectively. Subgroups 3-9 received sodium arsenite in drinking water $(50 \mathrm{mg} / \mathrm{L})$ [48]. In addition, subgroup 4 received NAC $(210 \mathrm{mg} / \mathrm{kg} \mathrm{b.wt})$ orally once daily [49], subgroups 5-7 received aqueous seed extract of $M$. pruriens ( $350 \mathrm{mg} / \mathrm{kg} \mathrm{b.wt}, 530 \mathrm{mg} / \mathrm{kg}$ b.wt, and $700 \mathrm{mg} / \mathrm{kg} \mathrm{b.wt)}$ orally once daily [50] and sub-groups 8 and 9 received a combination of NAC and aqueous seed extract of M. pruriens $(350 \mathrm{mg} / \mathrm{kg}$ b.wt and $530 \mathrm{mg} / \mathrm{kg}$ b.wt) orally once daily. The blood was drawn retro-orbitally $24 \mathrm{~h}$ after the treatment to assess the liver (serum alanine transaminase [ALT], aspartate transaminase [AST], and alkaline phosphatase [ALP]) and kidney (serum urea and serum creatinine) functions.

These following tests were performed using standard kits.

\section{Liver function tests}

- ALT (modified IFCC procedure)

- AST (Aspartate aminotransferase modified IFCC procedure)

- ALP (modified AMP procedure).

\section{Kidney function tests}

- Creatinine (modified Jaffe's method)

- Urea (urease/GLDH methodology). 


\section{Behavioral assessment}

After the treatment period, memory and learning were evaluated by the passive avoidance method.

\section{Passive avoidance learning apparatus [51]}

It includes three parts: (A) Exploration test, (B) Passive avoidance acquisition, (C) Retention test.

The equipment consisted of a small-sized dark compartment and a large-sized light compartment box separated by a sliding door that could be raised to $10 \mathrm{~cm}$. The stainless steel floor was connected to a shock stimulator that delivered the shock to the grid floor of the dark compartment.

\section{(A) Exploration test}

The sliding door separating the dark and light compartment was opened, and the rat was let to inspect both the compartments for $180 \mathrm{~s}$. The time in seconds spent by the rat in the small compartment in each trial was recorded. At the end of the trial, the rat was placed in the home cage, where it stayed during an inter-trial interval of $300 \mathrm{~s}$.

\section{(B) Passive avoidance acquisition}

The rat was placed in the small compartment, and the sliding door between the two compartments was closed. Three strong foot shocks $(50 \mathrm{~Hz}, 1.5 \mathrm{~mA}$, and 1-s duration) were delivered at a 5-s interval. After the experiment, the rat was placed in the home cage.

\section{(C) Retention test}

The retention test is carried out $24 \mathrm{~h}$ after foot shock. The rat was placed in the middle of the large compartment, facing away from the small compartment. The sliding door between the compartments was opened. The rat explored the small and the large compartments for $3 \mathrm{~min}$, after which it was placed back in the home cage. The trial was repeated thrice with an inter-trial interval of $5 \mathrm{~min}$. In each test, the time duration spent in the small compartment was noted.

A decrease in the time spent in the smaller compartment during retention test is considered as good memory retention performance.

\section{Cresyl violet staining and neural cell counting}

After the behavioral tests, the rats were euthanized and permeated with normal saline, followed by $10 \%$ formalin transcardially. The brains were removed and fixed in $10 \%$ formalin. $5 \mu \mathrm{m}$ thick paraffin sections were sliced using a rotary microtome and mounted on slides that were smeared with gelatin. Brain sections from each rat were then stained with $0.1 \%$ cresyl violet stain at $60^{\circ} \mathrm{C}$ for $20 \mathrm{~min}$. Ten sections per rat were selected for quantification. The quantification of surviving neural cells was done in CA1 and CA3 regions of the hippocampus, using a light microscope (Magnus MLX, Microscope). Surviving neural cells with a distinct and clear nucleus were considered for quantification, while darkly stained neural cells with irregular nuclei were not considered for quantification. The quantification was carried after the calibration of a light microscope using an ocular and stage micrometer (Erma, Japan).

\section{Statistical analysis}

The uniform data that were generated were depicted in terms of mean \pm standard deviation and were analyzed by one-way ANOVA followed by the post hoc Tukey test, and $\mathrm{p}<0.05$ was considered as statistically significant.

\section{Results}

\section{Passive avoidance test}

\section{In short-term treatment groups}

$24 \mathrm{~h}$ after foot shock was administered, animals treated with sodium arsenite showed decreased memory retention and spent $74.5 \%$ of the total duration in the dark compartment whereas animals in the normal control group spent $37.5 \%$ of the total duration in the dark compartment. Group treated with NAC showed results similar to the normal control group. Animals treated with M. pruriens $350 \mathrm{mg} / \mathrm{kg}$ b.wt, $530 \mathrm{mg} / \mathrm{kg}$ b.wt, and $700 \mathrm{mg} / \mathrm{kg}$ b.wt spent $69.27 \%, 55.57 \%$, and $60.5 \%$ of the total duration in the dark compartment, respectively, in comparison to sodium arsenite + NAC treated group (60\%). Animals treated with a combination of NAC $+M$. pruriens $350 \mathrm{mg} / \mathrm{kg}$ b.wt and NAC + M. pruriens $530 \mathrm{mg} / \mathrm{kg}$ b.wt spent $59.5 \%$ and $64.4 \%$ of the total time in the dark compartment, respectively. It was observed that there was a significant reduction in the time spent by the animals in the dark compartment in the groups treated with M. pruriens $530 \mathrm{mg} / \mathrm{kg}$ b.wt alone and a combination of NAC $+M$. pruriens $350 \mathrm{mg} / \mathrm{kg}$ b.wt (Table-1).

\section{In the long-term treatment groups}

$24 \mathrm{~h}$ after administration of the foot shock, the group treated with sodium arsenite spent $84.4 \%$ of the total time duration in the dark compartment showing poor memory retention. Normal controls $(42.03 \%)$ and

Table-1: Passive avoidance test results -45 days treatment.

\begin{tabular}{lcc}
\hline Groups & \multicolumn{2}{c}{ Retention } \\
\cline { 2 - 3 } & $\begin{array}{c}\text { Time spent in the } \\
\text { dark compartment } \\
\text { (sec) }\end{array}$ & $\begin{array}{c}\text { No. of } \\
\text { crossings }\end{array}$ \\
\hline Control & $73.67 \pm 20.03$ & $1.667 \pm 0.51$ \\
NAC & $75 \pm 16.85$ & $1.66 \pm 0.81$ \\
As control & $134.0 \pm 7.29 *$ & $3.98 \pm 0.81 *$ \\
As+NAC & $108.7 \pm 8.31$ & $2.16 \pm 0.98 \#$ \\
As+MP(350) & $124.7 \pm 36.04$ & $2.16 \pm 1.16 \#$ \\
As+MP(530) & $109.7 \pm 15.46 \#$ & $2.33 \pm 0.81 \#$ \\
As+MP(700) & $104.7 \pm 10.73$ & $1.83 \pm 0.75 \#$ \\
As+NAC+MP(350) & $107.2 \pm 8.29 \#$ & $2.03 \pm 0.63 \#$ \\
As+NAC+ MP(530) & $116 \pm 9.44$ & $1.16 \pm 0.81 \#$ \\
\hline In &
\end{tabular}

In each group $\mathrm{n}=6$. Values are mean $\pm \mathrm{SD}$. $* P<0.01$ : compared to the normal control group; $\# P<0.01$ compared to As control group. NAC - N-Acetylcysteine, As- arsenic, MP (350) - Mucuna pruriens aqueous seed extract $350 \mathrm{mg} / \mathrm{kg}$ body weight, MP (530) - Mucuna pruriens aqueous seed extract $530 \mathrm{mg} / \mathrm{kg}$ body weight, MP (700) - Mucuna pruriens aqueous seed extract $700 \mathrm{mg} / \mathrm{kg}$ body weight 
NAC $(43.15 \%)$ treated group showed similar results in the total time duration spent by the animals in the dark compartment. Animals treated with $M$. pruriens $350 \mathrm{mg} / \mathrm{kg}$ b.wt, $530 \mathrm{mg} / \mathrm{kg}$ b.wt, and $700 \mathrm{mg} / \mathrm{kg}$ b.wt spent $61.38 \%, 62.3 \%$, and $51.1 \%$ of the total duration in dark compartment, respectively, when compared to sodium arsenite treated group. Rats treated with M. pruriens $700 \mathrm{mg} / \mathrm{kg}$ b.wt spent significantly less time in the dark compartment in comparison to M. pruriens $350 \mathrm{mg} / \mathrm{kg}$ b.wt and $530 \mathrm{mg} / \mathrm{kg}$ b.wt groups. It was observed that rats treated with $M$. pruriens $700 \mathrm{mg} / \mathrm{kg}$ b.wt alone, and a combination of NAC $+M$. pruriens $350 \mathrm{mg} / \mathrm{kg}$ b.wt showed better memory retention (Table-2).

\section{Quantitative analysis of hippocampal neurons CA1 and $\mathrm{CA} 3$ region}

Short-term treatment

The CA1 and CA 3 regions of the hippocampus showed less surviving neurons in the sodium arsenite treated group when compared to normal control. Animals treated with M. pruriens $700 \mathrm{mg} / \mathrm{kg}$ b.wt indicated a significant increase in the number of surviving neurons in the CA1 region when compared to the sodium arsenite treated group. It was ascertained that $M$. pruriens $700 \mathrm{mg} / \mathrm{kg}$ b.wt alone and a combination of NAC $+M$. pruriens $350 \mathrm{mg} / \mathrm{kg} \mathrm{b} . \mathrm{wt}$ showed an increased number of surviving neurons in the CA1 region in comparison to other treatment groups.

Animals treated with $M$. pruriens $350 \mathrm{mg} / \mathrm{kg}$ b.wt, $530 \mathrm{mg} / \mathrm{kg}$ b.wt, and $700 \mathrm{mg} / \mathrm{kg}$ b.wt indicated an increased surviving neuronal number in the CA3 region when compared to sodium arsenite treated group. The number of surviving neurons in the group treated with $M$. pruriens $700 \mathrm{mg} / \mathrm{kg}$ b.wt was similar to the sodium arsenite + NAC treated group. Animals treated with NAC in combination with $M$. pruriens $350 \mathrm{mg} / \mathrm{kg}$ b.wt and $530 \mathrm{mg} / \mathrm{kg}$ b.wt showed an increased number of surviving neurons in the CA3 region when compared to sodium arsenite +NAC treated group (Table-3, Figures-1 and 2).

\section{Long-term treatment}

The number of surviving neurons decreased significantly in the hippocampal CA1 and CA3 regions following the administration of sodium arsenite. Normal control and NAC groups showed similar results with respect to the number of surviving neurons in the CA1 and the CA3 regions of the hippocampus. Rats treated with M. pruriens $530 \mathrm{mg} / \mathrm{kg}$ b.wt and $700 \mathrm{mg} / \mathrm{kg}$ b.wt showed a significant increase in the number of surviving neurons in the CA1 region when compared to sodium arsenite treated group. Animals treated with M. pruriens $700 \mathrm{mg} / \mathrm{kg}$ b.wt alone and combination of $\mathrm{NAC}+M$. pruriens $530 \mathrm{mg} / \mathrm{kg}$ b.wt exhibited results that were similar to sodium arsenite + NAC treated group. Animals treated with a combination of NAC and M. pruriens $530 \mathrm{mg} / \mathrm{kg}$ b.wt presented an increase in the surviving neurons when
Table-2: Passive avoidance test results - 90 days treatment.

\begin{tabular}{lcc}
\hline Groups & \multicolumn{2}{c}{ Retention } \\
\cline { 2 - 3 } & $\begin{array}{c}\text { Time spent in } \\
\text { small compartment } \\
\text { (sec) }\end{array}$ & $\begin{array}{c}\text { No. of } \\
\text { crossings }\end{array}$ \\
\hline Control & $75.67 \pm 12.02$ & $1.667 \pm 0.51$ \\
NAC & $77.67 \pm 7.98$ & $1.69 \pm 0.89$ \\
As control & $146.0 \pm 15.35 *$ & $4.12 \pm 0.81 *$ \\
As+NAC & $90.5 \pm 18.01 \#$ & $2.06 \pm 0.51 \#$ \\
As+MP(350) & $110.5 \pm 17.08 \#$ & $2.33 \pm 1.21 \#$ \\
As+MP(530) & $112 \pm 17.17 \#$ & $2.00 \pm 0.63 \#$ \\
As+MP(700) & $92 \pm 11.51 \#$ & $1.50 \pm 0.54 \#$ \\
As+NAC+MP(350) & $89.3 \pm 7.35 \#$ & $2.04 \pm 0.21 \#$ \\
As+NAC+MP(530) & $98.1 \pm 11.08 \#$ & $2.00 \pm 0.16 \#$ \\
\hline In &
\end{tabular}

In each group $\mathrm{n}=6$. Values are mean $\pm \mathrm{SD} . * P<0.01$ : compared to the normal control group; $\# P<0.01$ : compared to As control group. NAC - N-Acetylcysteine, As- arsenic, MP (350) - Mucuna pruriens aqueous seed extract $350 \mathrm{mg} / \mathrm{kg}$ body weight, MP (530) - Mucuna pruriens aqueous seed extract $530 \mathrm{mg} / \mathrm{kg}$ body weight, MP (700) - Mucuna pruriens aqueous seed extract $700 \mathrm{mg} / \mathrm{kg}$ body weight

Table-3: Effect of Mucuna pruriens on hippocampal neural cell quantification of sodium arsenite treated rats ( 45 days). The number of surviving neurons across 100-micron length.

\begin{tabular}{lcc}
\hline Groups & CA1 & CA3 \\
\hline Control & $48 \pm 7.07$ & $43 \pm 10.05$ \\
NAC & $50 \pm 15.3$ & $43 \pm 10.22$ \\
As control & $26 \pm 7.33^{*}$ & $23 \pm 9.99 *$ \\
As+NAC & $41 \pm 8.55$ & $37 \pm 9.13$ \\
As+MP(350) & $38 \pm 7.34$ & $34 \pm 2.57$ \\
As+MP(530) & $39 \pm 8.72$ & $36 \pm 4.27$ \\
As+MP(700) & $43 \pm 8.55 \#$ & $37 \pm 2.47$ \\
As+NAC +MP(350) & $43 \pm 6.92 \#$ & $38 \pm 10.22 \#$ \\
As+NAC+ MP(530) & $37 \pm 5.50$ & $37 \pm 2.57$ \\
\hline
\end{tabular}

In each group $\mathrm{n}=6$. Values are mean $\pm \mathrm{SD} . * P<0.01$ : compared to the normal control group; $\# P<0.01$ : compared to As control group. NAC - N-Acetylcysteine, As- arsenic, MP (350) - Mucuna pruriens aqueous seed extract $350 \mathrm{mg} / \mathrm{kg}$ body weight, MP (530) - Mucuna pruriens aqueous seed extract $530 \mathrm{mg} / \mathrm{kg}$ body weight, MP (700) - Mucuna pruriens aqueous seed extract $700 \mathrm{mg} / \mathrm{kg}$ body weight

compared to sodium arsenite +NAC group in the CA1 region.

Rats treated with $M$. pruriens $700 \mathrm{mg} / \mathrm{kg}$ b.wt alone and a combination of NAC and $M$. pruriens $(350 \mathrm{mg} / \mathrm{kg}$ b.wt and $530 \mathrm{mg} / \mathrm{kg}$ b.wt) showed a significant increase in the number of surviving neurons in the CA3 region when compared to sodium arsenite treated group. Animals treated with M. pruriens $350 \mathrm{mg} / \mathrm{kg}$ b.wt and $530 \mathrm{mg} / \mathrm{kg}$ b.wt showed an increase in the surviving neurons in the $\mathrm{CA} 3$ region when compared to sodium arsenite treated group. Rats treated with M. pruriens $700 \mathrm{mg} / \mathrm{kg}$ b.wt alone and a combination of $\mathrm{NAC}+M$. pruriens $530 \mathrm{mg} / \mathrm{kg}$ b.wt exhibited an increased number of surviving neurons in the CA3 region in comparison to sodium arsenite + NAC group (Table-4, Figures-3 and 4). 


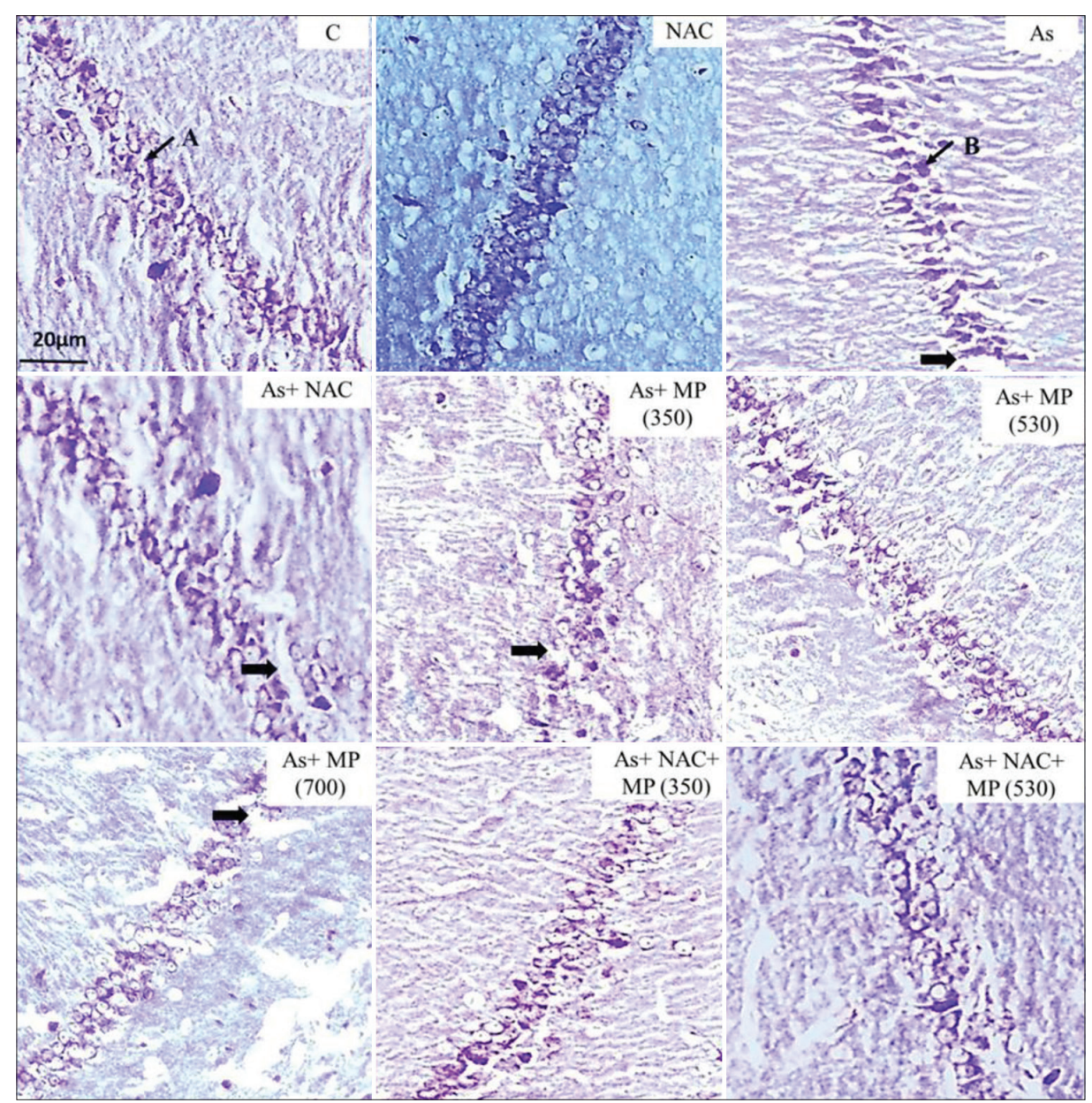

Figure-1: Representative photographs of CV stained sections of CA1 subfield of the hippocampus following 45 days of treatment, viewed under $100 \times$. The layering pattern showed disrupted pyramidal cell layers of $(\Rightarrow)$ the pyramidal cells in the treatment groups. A: Viable cell. B: Degenerated cell. Scale bar: $20 \mu \mathrm{m}$. NAC: N: Acetylcysteine, As: arsenic, MP (350): Mucuna pruriens aqueous seed extract $350 \mathrm{mg} / \mathrm{kg}$ body weight, MP (530): M. pruriens aqueous seed extract $530 \mathrm{mg} / \mathrm{kg}$ body weight, MP (700): M. pruriens aqueous seed extract $700 \mathrm{mg} / \mathrm{kg}$ body weight.

Table-4: Effect of Mucuna pruriens on hippocampal neural cell quantification of sodium arsenite treated rats (90 days). Number of surviving neurons across the 100-micron length.

\begin{tabular}{lcc}
\hline Groups & CA1 & CA3 \\
\hline Control & $51 \pm 7.79$ & $41 \pm 11.9$ \\
NAC & $50 \pm 8.9$ & $41 \pm 8.94$ \\
As control & $20 \pm 9.30 *$ & $15 \pm 8.85^{*}$ \\
As+NAC & $41 \pm 7.07 \#$ & $33 \pm 8.72 \#$ \\
As+MP(350) & $36 \pm 6.17$ & $29 \pm 5.21$ \\
As+MP(530) & $37 \pm 7.07 \#$ & $30 \pm 10.22$ \\
As+MP(700) & $41 \pm 15.07 \#$ & $32 \pm 9.82 \#$ \\
As+NAC+MP(350) & $42 \pm 4.79 \#$ & $34 \pm 2.29 \#$ \\
As+NAC+MP(530) & $41 \pm 7.79 \#$ & $32 \pm 4.22 \#$ \\
\hline
\end{tabular}

In each group $\mathrm{n}=6$. Values are mean $\pm \mathrm{SD}$. $* P<0.01$ : compared to the normal control group; $\# P<0.01$ : compared to As control group. NAC - N-Acetylcysteine, As- arsenic, MP (350) - Mucuna pruriens aqueous seed extract $350 \mathrm{mg} / \mathrm{kg}$ body weight, MP (530) - Mucuna pruriens aqueous seed extract $530 \mathrm{mg} / \mathrm{kg}$ body weight, MP (700) - Mucuna pruriens aqueous seed extract $700 \mathrm{mg} / \mathrm{kg}$ body weight

\section{Effect on liver and kidney functions}

\section{Short-term treatment}

Sodium arsenite administration significantly increased the levels of liver and kidney enzymes in serum when compared to normal controls indicating toxicity. The levels of liver enzymes (AST, ALT, and ALP) showed a decrease in the groups treated with M. pruriens $350 \mathrm{mg} / \mathrm{kg} \mathrm{b.wt,} 530 \mathrm{mg} / \mathrm{kg} \mathrm{b.wt,} \mathrm{and}$ $700 \mathrm{mg} / \mathrm{kg}$ b.wt in comparison to sodium arsenite treated group, which was not statistically significant. Animals treated with a combination of sodium arsenite + NAC along with $M$. pruriens $350 \mathrm{mg} / \mathrm{kg}$ b.wt showed a significant decrease in serum ALT levels when compared to sodium arsenite treated group (Tables-5 and 6).

A decrease in the levels of kidney enzymes (creatinine and urea) in serum was observed in animals treated with $M$. pruriens $(350 \mathrm{mg} / \mathrm{kg}$ b.wt, $530 \mathrm{mg} / \mathrm{kg} \mathrm{b.wt}$, and $700 \mathrm{mg} / \mathrm{kg} \mathrm{b.wt)} \mathrm{along} \mathrm{with}$ sodium arsenite, and combination of sodium arsenite +NAC along with $M$. pruriens $(350 \mathrm{mg} / \mathrm{kg}$ b.wt and $530 \mathrm{mg} / \mathrm{kg} \mathrm{b.wt)}$ when compared to sodium arsenite group, which was not statistically significant. Animals treated with a combination of sodium arsenite $+\mathrm{NAC}$ along with $M$. pruriens $530 \mathrm{mg} / \mathrm{kg}$ b.wt had serum urea levels similar to As+ NAC treated group.

\section{Long-term treatment}

Sodium arsenite treatment significantly increased the levels of liver and kidney enzymes in 


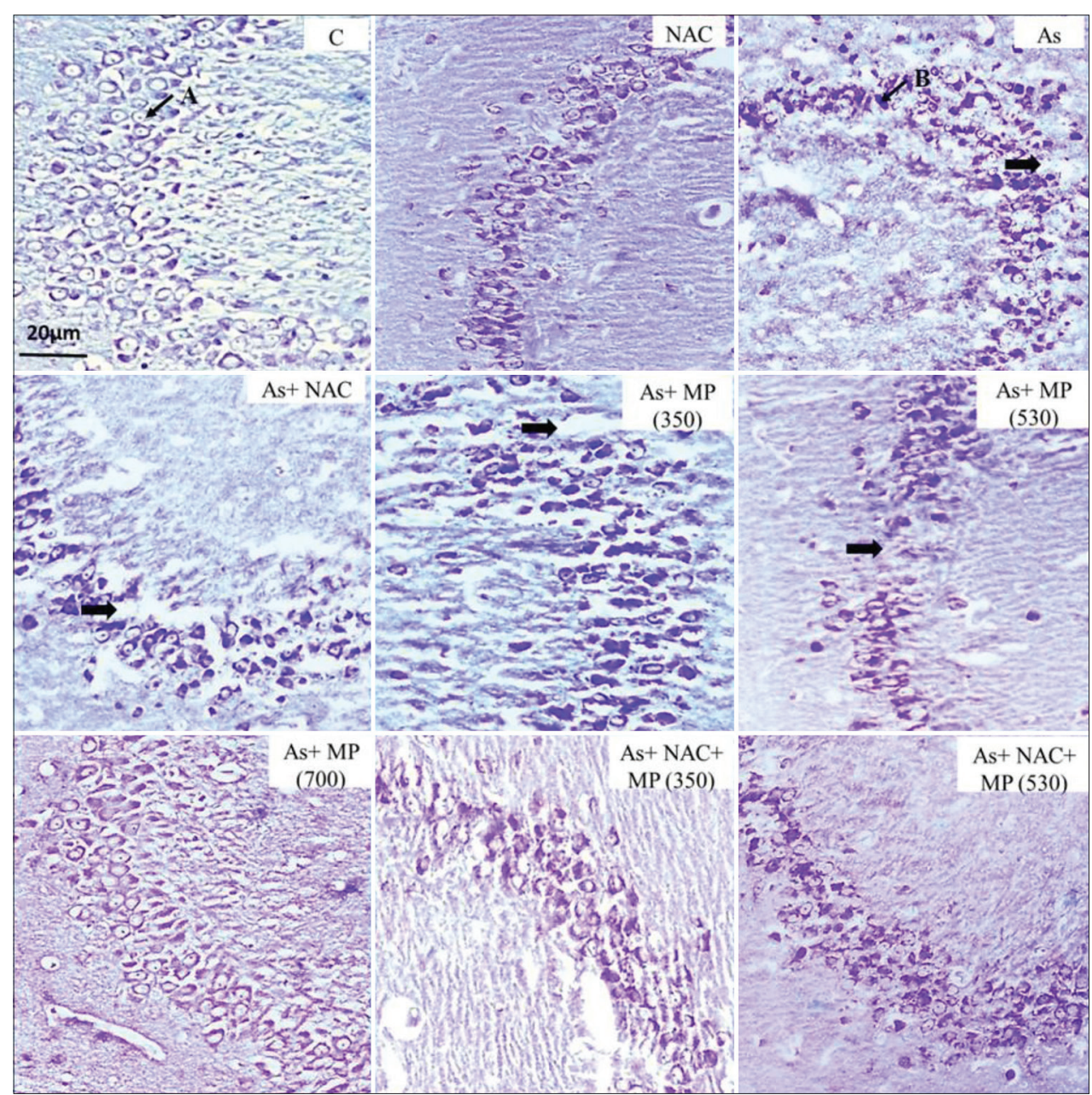

Figure-2: Representative photographs of CV stained sections of CA3 subfield of the hippocampus following 45 days of treatment, viewed under $100 \times$. The layering pattern showed disrupted pyramidal cell layers of $\Rightarrow$ ) the pyramidal cells in the treatment groups. A: Viable cell. B: Degenerated cell. Scale bar: $20 \mu \mathrm{m}$. NAC: N-Acetylcysteine, As: arsenic, MP (350): Mucuna pruriens aqueous seed extract $350 \mathrm{mg} / \mathrm{kg}$ body weight, MP (530)-M. pruriens aqueous seed extract $530 \mathrm{mg} / \mathrm{kg}$ body weight, MP (700): M. pruriens aqueous seed extract $700 \mathrm{mg} / \mathrm{kg}$ body weight.

Table-5: Effect of Mucuna pruriens (45 days) on liver function tests in the serum of arsenic-treated rats

\begin{tabular}{lccc}
\hline Groups & AST (U/L) & ALT $(\mathbf{U} / \mathbf{L})$ & ALP $(\mathbf{U} / \mathbf{L})$ \\
\hline Control & $100.3 \pm 9.67$ & $37.78 \pm 4.05$ & $107.4 \pm 10.22$ \\
NAC & $105.6 \pm 12.61$ & $38.19 \pm 3.89$ & $111.0 \pm 5.21$ \\
As control & $140.5 \pm 9.13 *$ & $49.8 \pm 2.30 *$ & $159.7 \pm 28.86 *$ \\
As+NAC & $110.6 \pm 22.28 \#$ & $40.21 \pm 4.31 \#$ & $139.4 \pm 11.99$ \\
As+MP(350) & $126.6 \pm 9.27$ & $45.11 \pm 5.43$ & $154.1 \pm 8.72$ \\
As+MP(530) & $124.2 \pm 13.62$ & $43.1 \pm 5.99$ & $149.6 \pm 11.94$ \\
As+MP(700) & $121 \pm 8.85$ & $41.56 \pm 5.11$ & $146.5 \pm 9.99$ \\
As+NAC & $119.48 \pm 9.32$ & $40.34 \pm 3.9 \#$ & $148 \pm 11.9$ \\
+MP(350) & & & \\
As+NAC+ & $117.48 \pm 12.52$ & $42.32 \pm 3.16$ & $145 \pm 10.7$ \\
MP(530) & & & \\
\hline
\end{tabular}

In each group $\mathrm{n}=6$. Values are mean $\pm \mathrm{SD}$. $* P<0.01$ : compared to the normal control group; $\# P<0.01$ : compared to As control group. NAC - N-Acetylcysteine, As- arsenic, MP (350) - Mucuna pruriens aqueous seed extract $350 \mathrm{mg} / \mathrm{kg}$ body weight, MP (530) - Mucuna pruriens aqueous seed extract $530 \mathrm{mg} / \mathrm{kg}$ body weight, MP (700) - Mucuna pruriens aqueous seed extract $700 \mathrm{mg} / \mathrm{kg}$ body weight

serum when compared to normal control indicating toxicity. Administration of all doses of M. pruriens (350 mg/kg b.wt, $530 \mathrm{mg} / \mathrm{kg} \mathrm{b.wt,} \mathrm{and} 700 \mathrm{mg} / \mathrm{kg}$ b.wt) along with sodium arsenite led to a significant
Table-6: Effect of Mucuna pruriens (45 days) on kidney function tests in the serum of arsenic-treated rats

\begin{tabular}{lcc}
\hline Groups & Creatinine $(\mathbf{U} / \mathbf{L})$ & Urea $(\mathbf{U} / \mathbf{L})$ \\
\hline Control & $0.83 \pm 0.11$ & $34.02 \pm 3.6$ \\
NAC & $0.81 \pm 0.32$ & $37.19 \pm 2.26$ \\
As control & $1.38 \pm 0.12^{*}$ & $45.20 \pm 2.40 *$ \\
As+NAC & $1.04 \pm 0.26 \#$ & $41.26 \pm 3.33$ \\
As+MP(350) & $1.17 \pm 0.81$ & $42.93 \pm 6.88$ \\
As+MP(530) & $1.08 \pm 0.11$ & $43.5 \pm 4.80$ \\
As+MP(700) & $1.10 \pm 0.06$ & $42.18 \pm 2.68$ \\
As+NAC+ & $1.09 \pm 0.05$ & $43.32 \pm 2.68$ \\
MP(350) & & \\
As+NAC+ & $1.11 \pm 0.01$ & $41.26 \pm 4.59$ \\
MP(530) & &
\end{tabular}

In each group $\mathrm{n}=6$. Values are mean $\pm \mathrm{SD}$. $* P<0.01$ : compared to the normal control group; $\# P<0.01$ : compared to As control group. NAC - N-Acetylcysteine, As- arsenic, MP (350) - Mucuna pruriens aqueous seed extract $350 \mathrm{mg} / \mathrm{kg}$ body weight, MP (530) - Mucuna pruriens aqueous seed extract $530 \mathrm{mg} / \mathrm{kg}$ body weight, MP (700) - Mucuna pruriens aqueous seed extract $700 \mathrm{mg} / \mathrm{kg}$ body weight.

decline in levels of liver and kidney enzymes in serum when compared to sodium arsenite treated rats. Levels of serum ALT were similar in the group treated with the combination of sodium arsenite + 


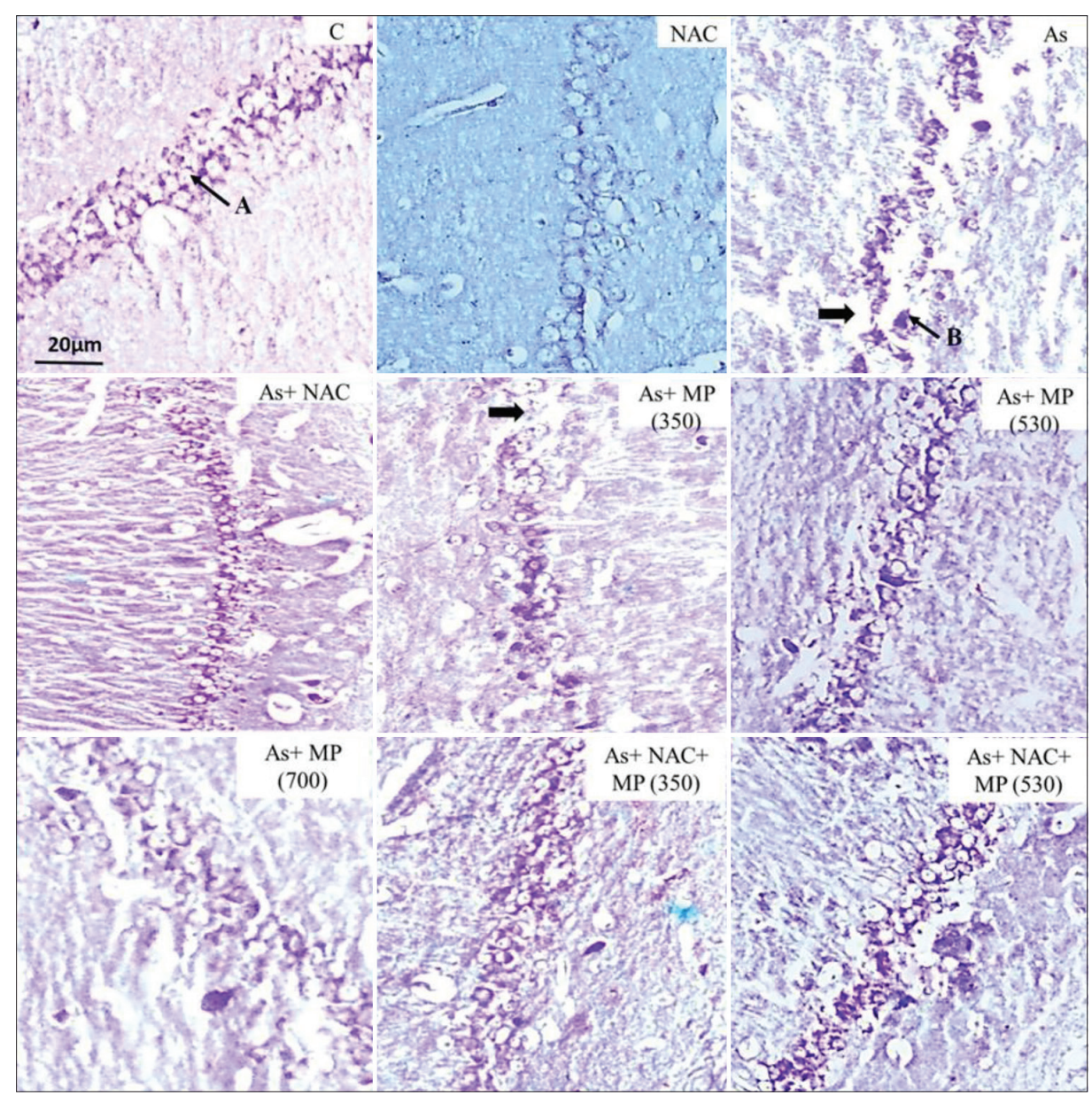

Figure-3: Representative photographs of CV stained sections of CA1 subfield of the hippocampus following 90 days of treatment, viewed under $100 \times$. The layering pattern showed disrupted pyramidal cell layers of $(\Rightarrow)$ the pyramidal cells in the treatment groups. A: Viable cell. B: Degenerated cell. Scale bar: $20 \mu \mathrm{m}$. NAC: N-Acetylcysteine, As: arsenic, MP (350): Mucuna pruriens aqueous seed extract $350 \mathrm{mg} / \mathrm{kg}$ body weight, MP (530): M. pruriens aqueous seed extract $530 \mathrm{mg} / \mathrm{kg}$ body weight, MP (700): M. pruriens aqueous seed extract $700 \mathrm{mg} / \mathrm{kg}$ body weight.

NAC along with $M$. pruriens $530 \mathrm{mg} / \mathrm{kg}$ b.wt, and sodium arsenite + NAC group. Animals treated with M. pruriens $700 \mathrm{mg} / \mathrm{kg}$ b.wt showed serum ALP levels similar to sodium arsenite + NAC group, thus showing a better response.

Animals treated with $M$. pruriens $700 \mathrm{mg} / \mathrm{kg}$ b.wt alone and in combination with $\mathrm{NAC}+M$. pruriens $(350 \mathrm{mg} / \mathrm{kg}$ b.wt and $530 \mathrm{mg} / \mathrm{kg}$ b.wt) showed a decrease in the levels of serum creatinine when compared to sodium arsenite + NAC group. Treatment with sodium arsenite $+M$. pruriens $700 \mathrm{mg} / \mathrm{kg}$ b.wt, and combination of sodium arsenite + NAC along with $M$. pruriens at doses $350 \mathrm{mg} / \mathrm{kg}$ b.wt and $530 \mathrm{mg} / \mathrm{kg}$ b.wt showed a significant decline in the levels of serum urea. However, the improvement was more significant in rats treated with $700 \mathrm{mg} / \mathrm{kg}$ b.wt M. pruriens extract (Tables-7 and 8).

\section{Discussion}

The brain is liable to oxidative deterioration due to an increase in oxygen usage, a high amount of polyunsaturated fatty acids [52], and a lack of antioxidant defense mechanism. Arsenic permeates the blood-brain barrier resulting in damage to the nervous
Table-7: Effect of Mucuna pruriens (90 days) on liver function tests in the serum of arsenic-treated rats

\begin{tabular}{lccc}
\hline Groups & $\begin{array}{c}\text { Serum AST } \\
(\mathbf{U} / \mathbf{L})\end{array}$ & $\begin{array}{c}\text { Serum ALT } \\
(\mathbf{U} / \mathbf{L})\end{array}$ & $\begin{array}{c}\text { Serum ALP } \\
(\mathbf{U} / \mathbf{L})\end{array}$ \\
\hline Control & $100.1 \pm 8.55$ & $38.12 \pm 4.36$ & $107.1 \pm 7.03$ \\
NAC & $98.89 \pm 25.36$ & $37.69 \pm 4.60$ & $110.7 \pm 15.12$ \\
As control & $148.5 \pm 12.89 *$ & $54.7 \pm 4.97 *$ & $163.4 \pm 11.76 *$ \\
As+NAC & $109.5 \pm 16.6 \#$ & $40.26 \pm 5.43 \#$ & $130.9 \pm 8.65 \#$ \\
As+MP & $125.1 \pm 14.18$ & $44.52 \pm 2.81 \#$ & $138.7 \pm 19.82$ \\
$(350)$ & & & \\
As+MP & $123.6 \pm 10.16$ & $43.08 \pm 2.09 \#$ & $130.6 \pm 16.22 \#$ \\
(530) & & & \\
As+MP & $109.8 \pm 17.97 \#$ & $41.17 \pm 6.69 \#$ & $124.1 \pm 12.52 \#$ \\
(700) & & & \\
As+NAC+ & $119.1 \pm 12.10$ & $43.35 \pm 2.40 \#$ & $131.6 \pm 8.50 \#$ \\
MP(350) & & & \\
As+NAC+ & $116.6 \pm 8.87 \#$ & $40.79 \pm 6.01 \#$ & $132.5 \pm 7.12 \#$ \\
MP(530) & & & \\
\hline
\end{tabular}

In each group $\mathrm{n}=6$. Values are mean \pm SD. $* P<0.01$ : compared to the normal control group; $\# P<0.01$ : compared to As control group. NAC - N-Acetylcysteine, As- arsenic, MP (350) - Mucuna pruriens aqueous extract $350 \mathrm{mg} / \mathrm{kg}$ body weight, MP (530) - Mucuna pruriens aqueous extract $530 \mathrm{mg} / \mathrm{kg}$ body weight, MP (700) Mucuna pruriens aqueous extract $700 \mathrm{mg} / \mathrm{kg}$ body weight.

system $[53,54]$. In this study, rats were exposed to sodium arsenite through drinking water. Passive 


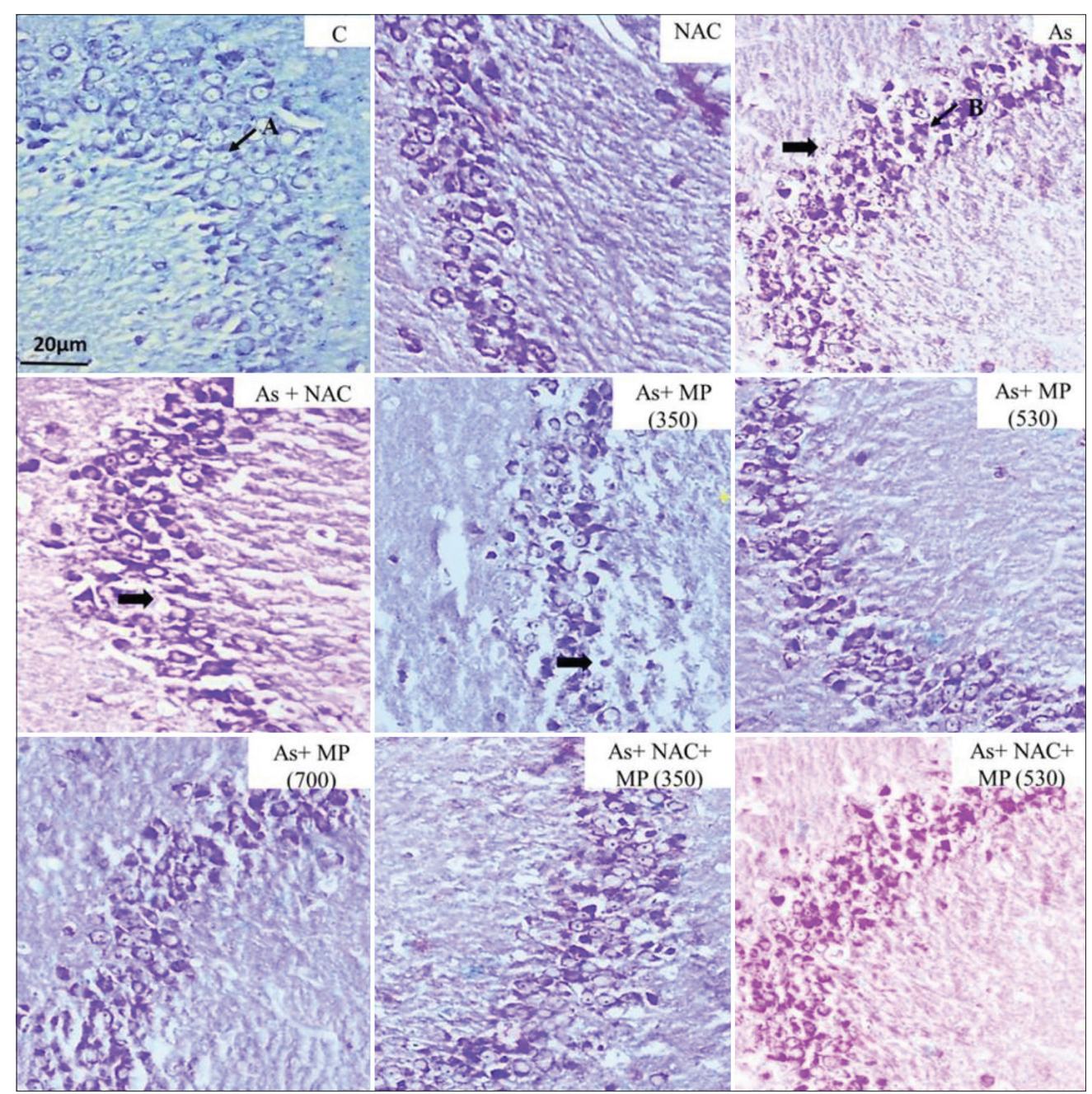

Figure-4: Representative photographs of CV stained sections of CA3 subfield of the hippocampus following 90 days of treatment, viewed under $100 \times$. The layering pattern showed disrupted pyramidal cell layers of $(\Rightarrow)$ the pyramidal cells in the treatment groups. A: Viable cell. B: Degenerated cell. Scale bar: $20 \mu \mathrm{m}$. NAC: N: Acetylcysteine, As: arsenic, MP (350): Mucuna pruriens aqueous seed extract $350 \mathrm{mg} / \mathrm{kg}$ body weight, MP (530): M. pruriens aqueous seed extract $530 \mathrm{mg} / \mathrm{kg}$ body weight, MP (700): M. pruriens aqueous seed extract $700 \mathrm{mg} / \mathrm{kg}$ body weight.

Table-8: Effect of Mucuna pruriens (90 days) on kidney function tests in the serum of arsenic-treated rats

\begin{tabular}{lcc}
\hline Groups & $\begin{array}{c}\text { Serum creatinine } \\
(\mathbf{U} / \mathbf{L})\end{array}$ & $\begin{array}{c}\text { Serum urea } \\
(\mathbf{U} / \mathbf{L})\end{array}$ \\
\hline Control & $0.97 \pm 0.13$ & $37.2 \pm 3.79$ \\
NAC & $0.99 \pm 0.12$ & $37.45 \pm 2.55$ \\
As control & $1.59 \pm 0.24 *$ & $54.93 \pm 3.90^{*}$ \\
As+NAC & $1.05 \pm 0.17 \#$ & $48.42 \pm 2.13 \#$ \\
As+MP(350) & $1.22 \pm 0.13 \#$ & $49.61 \pm 3.22$ \\
As+MP(530) & $1.08 \pm 0.15 \#$ & $50.90 \pm 2.68$ \\
As+MP(700) & $0.98 \pm 0.12 \#$ & $42.75 \pm 2.69 \#$ \\
As+NAC+MP(350) & $1.02 \pm 0.26 \#$ & $46.27 \pm 1.50 \#$ \\
As+NAC+MP(530) & $1.04 \pm 0.24 \#$ & $44.49 \pm 3.37 \#$ \\
\hline
\end{tabular}

Values are mean $\pm S D,(n=6)$ in each group. $* P<0.01$ :

compared to the normal control group; $\# P<0.01$ : compared to As control group. NAC - N-Acetylcysteine, As- arsenic, MP (350) - Mucuna pruriens aqueous extract $350 \mathrm{mg} / \mathrm{kg}$ body weight, MP (530) - Mucuna pruriens aqueous extract $530 \mathrm{mg} / \mathrm{kg}$ body weight, MP (700) -

Mucuna pruriens aqueous extract $700 \mathrm{mg} / \mathrm{kg}$ body weight.

avoidance test results showed reduced learning and memory in sodium arsenite treated animals along with a decreased number of hippocampal neural cells. Accumulation of arsenic in the hippocampus caused neurodegeneration, thereby bringing about deficits in memory and learning [7,55]. Histopathology showed neurons that were darkly stained with small nuclei. In this study, there was a decrease in the neuronal cell number in the sodium arsenite treated group in comparison to the normal control. In a study carried out by Luo et al., [56], a marked decrease in epinephrine, dopamine, and serotonin was noted in the hippocampus following prolonged exposure to arsenic [57]. Increased neuronal cell apoptosis of the brain has been reported on chronic arsenic exposure [58]. The findings of the subject study showed a decrease in cell number in the hippocampus on arsenic exposure, agreeing with the previously reported work. Arsenic exposure increases the production of free radicals, which damages the lipids, proteins, and DNA [3], leading to a reduction in the cognitive process and also blocks the sulfhydryl groups of enzymes and proteins [59]. The neurodegeneration caused by arsenic is due to synaptic injury, free radical production, and lipid peroxidation [60]. In a study carried out by Tavarekere et al., [61], it was found that learning 
and memory deficits that were observed were due to a decrease in the acetylcholinesterase activity in the brain following arsenic exposure. The previous studies have demonstrated arsenic-induced neuronal cell death through potential mechanisms like oxidative stress [62-64].

Liver cell integrity is measured by estimating the AST and ALT enzyme levels. Enzyme levels of ALP are a measure of albumin and bile synthesis by the liver. Studies have told that increased measures of AST and ALT in the plasma of rats exposed to arsenic are mainly due to damage to the hepatic cell membrane. This damage increases membrane permeability resulting in leakage of cellular contents $[19,65]$. Following previous reports, we observed significantly higher levels of AST and ALT in rats exposed to arsenic when compared to healthy controls. Arsenic toxicity leads to inhibition of cellular respiration in mitochondria [66], enhancing the generation of ROS. This further causes an increase in lipid peroxidation and damage to the cells [67].

Studies have reported an association between the rise in arsenic levels in the blood and elevated concentrations of serum urea, creatinine, and damage to the tubules $[68,69]$. Animal experiments and epidemiologic studies in humans have clearly shown that acute and chronic arsenic exposure can damage the kidneys and increase the risk of cancer [70]. According to Gora et al., [69], there was an exceptional increase in the BUN and creatinine levels following exposure to arsenic in rats. The proximal convoluted tubule cells are sensitive to toxicity induced by arsenic due to their reabsorptive function [20]. Arsenic reacts with compounds containing the sulfhydryl group [59]. It inhibits the GSH reductase and produces excessive ROS in the kidney, which will lead to damage of the respective organ [71]. According to the results in this study, the increased concentrations of serum urea and serum creatinine in 90 days treatment support greater involvement of the renal tubular cells in the excretion of arsenic, making them prone to damage.

Seeds of $M$. pruriens contain bioactive compounds such as flavonoids, alkaloids, tannins, and phenolic compounds [72]. It also contains levodopa, which can cross the blood-brain barrier and restore neurotransmission [39]. It has a positive effect on learning and memory. Polyphenols and quercetin, which are the components of $M$. pruriens, exert their anti-inflammatory and iron-chelating properties in the brain [73]. Besides, in MPTP treated animals, treatment with $M$. pruriens suppressed the inflammatory response due to glial cell activation and dopaminergic neuronal loss [74]. It also exhibits a potent antioxidant, anti-inflammatory, and free-radical scavenging activity. Flavonoids are responsible for the radical-trapping properties and are efficient against the destruction that is mediated by ROS [75]. Thus, it can protect liver tissue from arsenic-induced ROS and prevents inflammation and hepatic cellular death in M. pruriens extract-treated group. M. pruriens seed extract decreased the lipid peroxidation in the liver and kidney tissue of diabetic rats in a dose-dependent manner [76].

Even though increased arsenic levels in drinking water (above $50 \mu \mathrm{g} / \mathrm{L}$ ) have been reported in many countries such as Nepal, Argentina, China, Japan, and Vietnam, the main stirred areas are situated in Bangladesh and West Bengal in India. The arsenic concentrations in groundwater in these areas have been documented up to $3200 \mu \mathrm{g}[77,78]$. Since arsenic-rich drinking water is inevitable in these areas, the susceptibility of organ toxicity further leading to damage is also unavoidable. Handling of toxicity is to be done in such a way that the body should not be burdened further. In this context, plant-based treatment may help, as the body can easily handle them without side effects. Further, M. pruriens is proved to have nutritional and medicinal values [39]. Therefore, M. pruriens can be administered in the diet of people affected by arsenic so that both the nutritional and medicinal needs are taken care of.

\section{Conclusion}

Administration of $M$. pruriens with sodium arsenite improves memory retention and prevents neurodegeneration of the CA1 and CA3 regions of the hippocampus in short- and long-term treatment groups. It also improves the liver and kidney functions in long-term treatment groups. It can be concluded that these beneficial effects of $M$. pruriens are due to its antioxidant property.

\section{Authors' Contributions}

PC and LKB designed the study. PC performed the research and drafted the manuscript. PC and LKB analyzed the data. PC, LKB, and APR revised and finalized the manuscript for submission. All authors read and approved the final manuscript.

\section{Acknowledgments}

We would like to thank the Manipal Academy of Higher Education for providing the infrastructure for conducting the study. The authors did not receive any funds for this study.

\section{Competing interests}

The authors declare that they have no competing interests.

\section{Publisher's Note}

Veterinary World remains neutral with regard to jurisdictional claims in published institutional affiliation.

\section{References}

1. Herath, I., Vithanage, M. and Bundschuh, J. (2016) Natural arsenic in global groundwaters: Distribution and geochemical triggers for mobilization. J. Curr. Pollut. Rep., 2(1): 68-69. 
2. Lalwani, S., Dogra, T.D., Bhardwaj, D.N., Sharma, R.K. and Murty, O.P. (2006) Study on arsenic level in public water supply of Delhi using hydride generator accessory coupled with atomic absorption spectrophotometer. Indian. J. Clin. Biochem., 21(1): 70-76.

3. Ratnaike, R.N. (2003) Acute and chronic arsenic toxicity, review. Postgrad. Med. J., 79(933): 391-396.

4. Levin-Scherz, J.K., Patrick, J.D., Weber, F.H. and Garabedian, C.Jr. (1987) Acute arsenic ingestion. Ann. Emerg. Med., 6(6): 702-704.

5. Simeonova, P.P. and Luster, M.I. (2004) Arsenic and atherosclerosis. Toxicol. Appl. Pharmacol. 198(3): 444-449.

6. Rahman, M.M., Chowdhury, U.K., Mukherjee, S.C., Mondal, B.K., Paul, K., Lodh, D., Biswas, B.K., Chanda, C.R., Basu, G.K., Saha, K.C., Roy, S., Das, R., Palit, S.K., Quamruzzaman, Q. and Chakraborti, D. (2001) Chronic arsenic toxicity in Bangladesh and West Bengal, India a review and commentary. J. Toxicol. Clin. Toxicol., 39(7): 683-700.

7. Tyler, C.R. and Allan, A.M. (2014) The effects of arsenic exposure on neurological and cognitive dysfunction in human and rodent studies: A review. Curr. Environ. Health Rep., 1(2): 132-147.

8. Liu, S., Piao, F., Sun, X., Bai, L., Peng, Y., Zhong, Y. and Sun, W. (2012) Arsenic-induced inhibition of hippocampal neurogenesis and its reversibility. Neurotoxicology, 33(5): 1033-1039.

9. Yadav, R.S., Chandravanshi, L.P., Shukla, R.K., Sankhwar, M.L., Ansari, R.W., Shukla, P.K., Pant, A.B. and Khanna, V.K. (2011) Neuroprotective efficacy of curcumin in arsenic induced cholinergic dysfunctions in rats. Neurotoxicology, 32(6): 760-768.

10. Gong, G., Hargrave, K.A., Hobson, V., Spallholz, J., Boylan, M., Lefforge, D. and O'Bryant, S.E. (2011) Lowlevel groundwater arsenic exposure impacts cognition: A project FRONTIER study. J. Environ. Health, 74(2): 16-22.

11. Escudero-Lourdes C. (2016) Toxicity mechanisms of arsenic that are shared with neurodegenerative diseases and cognitive impairment: Role of oxidative stress and inflammatory responses. Neurotoxicology, 53: 223-235.

12. Li, W. and Chou, I.N. (1992) Effects of sodium arsenite on the cytoskeleton and cellular glutathione levels in cultured cells. Toxicol. Appl. Pharmacol., 114(1): 132-139.

13. Aung, K.H., Tsukahara, S., Maekawa, F., Nohara, K., Nakamura, K. and Tanoue, A. (2015) Role of environmental chemical insult in neuronal cell death and cytoskeleton damage. Biol. Pharm. Bull., 38(8): 1109-1112.

14. Kulshrestha, A., Jarouliya, U., Prasad, G., Flora, S. and Bisen, P.S. (2014) Arsenic-induced abnormalities in glucose metabolism: Biochemical basis and potential therapeutic and nutritional interventions. World J. Transl. Med., 3(2): 96-11.

15. Most, P. and Papenbrock, J. (2015) Possible roles of plant sulfurtransferases in detoxification of cyanide, reactive oxygen species, selected heavy metals and arsenate. Molecules, 20(1): 1410-1423.

16. Kim, J.H., Byun, H.M., Chung, E.C., Chung, H.Y. and Bae. (2013) Loss of integrity: Impairment of the blood-brain barrier in heavy metal-associated ischemic stroke. Toxicol. Res., 29(3): 157-164.

17. Kaler, S., Dhar, P., Bhattacharya, A. and Mehra, R.D. (2013) Preliminary morphological and immunohistochemical changes in rat hippocampus following postnatal exposure to sodium arsenite. Toxicol. Int., 20(2): 160-169.

18. Garbarino, V.R., Orr, M.E., Rodriguez, K.A. and Buffenstein, R. (2015) Mechanisms of oxidative stress resistance in the brain: Lessons learned from hypoxia tolerant extremophilic vertebrates. Arch. Biochem. Biophys., 576: 8-16.

19. Jiang, S., Su, J. and Yao, S. (2014) Fluoride and arsenic exposure impairs learning and memory and decreases mGluR5 expression in the hippocampus and cortex in rats.
PLoS One, 9(4): e96041.

20. Orr, S.E. and Bridges, C.C. (2017) Chronic kidney disease and exposure to nephrotoxic metals. Int. J. Mol. Sci., 18(5): 1039.

21. Liu, J. and Waalkes, M.P. (2008) Liver is a target of arsenic carcinogenesis. Toxicol. Sci., 105(1): 24-32.

22. Yang, H.C., Fu, H.L., Lin, Y.F. and Rosen, B.P. (2012) Pathways of arsenic uptake and efflux. Curr. Top. Membr., 69: 325-358

23. Druwe, I.L. and Vaillancourt, R.R. (2010) Influence of arsenate and arsenite on signal transduction pathways: An update. Arch. Toxicol., 84(8): 585-596.

24. Das, N., Paul, S., Chatterjee, D., Banerjee, N., Majumder, N.S., Sarma, N., Sau, T.J., Basu, S., Banerjee, S., Majumder, P., Bandyopadhyay, A.K., States, J.C. and Giri, A.K. (2012) Arsenic exposure through drinking water increases the risk of liver and cardiovascular diseases in the population of West Bengal, India. BMC. Public Health, 10(12): 639.

25. Cui, X., Li, S., Shraim, A., Kobayashi, Y., Hayakawa, T., Kanno, S. and Hirano, S. (2004) Subchronic exposure to arsenic through drinking water alters expression of cancer-related genes in rat liver. Toxicol. Pathol., 32(1): 64-72.

26. Tan, M., Schmidt, R.H., Beier, J.I., Watson, W.H., Zhong, H., States, J.C. and Arteel, G.E. (2011) Chronic sub hepatotoxic exposure to arsenic enhances hepatic injury caused by high fat diet in mice. Toxicol. Appl. Pharmacol., 257(3): 356-364.

27. Tchounwou, P.B., Patlolla, A.K. and Centeno, J.A. (2003) Carcinogenic and systemic health effects associated with arsenic exposure--a critical review. Toxicol. Pathol., 31(6): 575-588.

28. Tokar, E.J, Benbrahim-Tallaa, L., Ward, J.M., Lunn, R., Sams, R.L. and Waalkes, M.P. (2010) Cancer in experimental animals exposed to arsenic and arsenic compounds. Crit. Rev. Toxicol., 40(10): 912-927.

29. Li, Z., Piao, F., Liu, S., Wang, Y. and Qu, S. (2010) Subchronic exposure to arsenic trioxide-induced oxidative DNA damage in kidney tissue of mice. Exp. Toxicol. Pathol., 62(5): 543-547.

30. Griffin, K.A., Picken, M.M., Churchill, M., Churchill, P. and Bidani, A.K. (2000) Functional and structural correlates of glomerulosclerosis after renal mass reduction in the rat. J. Am. Soc. Nephrol., 11(3): 497-506.

31. Cheng, Y.Y., Huang, N.C., Chang, Y.T., Sung, J.M., Shen, K.H., Tsai, C.C. and Guo, H.R. (2017) Associations between arsenic in drinking water and the progression of chronic kidney disease: A nationwide study in Taiwan. $J$. Hazard. Mater., 321: 432-439.

32. Robles-Osorio, M.L., Sabath-Silva, E. and Sabath, E. (2015) Arsenic-mediated nephrotoxicity. Ren. Fail., 37(4): 542-547.

33. Noman, A.S., Dilruba, S. and Mohanto, N.C. (2015) Arsenic-induced histological alterations in various organs of mice. J. Cytol. Histol., 6(3): 323.

34. Kenyon, E.M., Del Razo, L.M. and Hughes, M.F. (2005) Tissue distribution and urinary excretion of inorganic arsenic and its methylated metabolites in mice following acute oral administration of arsenate. Toxicol. Sci., 85(1): 468-475.

35. Van Zandwijk, N. (1995) N-Acetylcysteine (NAC) and glutathione (GSH): Antioxidant and chemopreventive properties, with special reference to lung cancer. J. Cell. Biochem. Suppl., 59(22): 24-32.

36. Shahripour, R.B., Harrigan, M.R. and Alexandrov, A.V. (2014) N-acetylcysteine (NAC) in neurological disorders: Mechanisms of action and therapeutic opportunities. Brain Behav., 4(2): 108-122.

37. Xue, C., Liu, W., Wu, J., Yang, X. and Xu, H. (2011) Chemoprotective effect of N-acetylcysteine (NAC) on cellular oxidative damages and apoptosis induced by nano titanium dioxide under UVA irradiation. Toxicol. In Vitro, 
25(1): $110-116$.

38. Zhang, L., Zhu, Z., Liu, J., Zhu, Z. and Hu, Z. (2014) Protective effect of N-acetylcysteine (NAC) on renal ischemia/reperfusion injury through Nrf2 signaling pathway. $J$. Recept. Signal Transduct. Res., 34(5): 396-400.

39. Lampariello, L.R., Cortelazzo, A., Guerranti, R., Sticozzi, C. and Valacchi, G. (2012) The magic velvet bean of Mucuna pruriens. J. Tradit. Complement. Med., 2(4): 331-339.

40. Rajeshwar, Y., Gupta, M. and Mazumdar, U.K. (2005) In vitro lipid peroxidation and antimicrobial activity of Mucuna pruriens seeds. Iran. J. Pharmacol. Ther., 4(1): 32-35.

41. Modi, K. (2013) Protective effects of aqueous extract of $M$. pruriens Linn. (DC) seed against cisplatin-induced oxidative stress and nephrotoxicity in rats. Afr. J. Pharm. Pharmacol., 7(28): 1994-1999.

42. Kasture, S., Mohan, M. and Kasture, V. (2013) Mucuna pruriens seeds in treatment of Parkinson's disease: Pharmacological review. Orient. Pharm. Exp. Med., 13(3): 165-174

43. Sampath, M. (2011) Neuroprotective effects of Mucuna pruriens against stress-induced oxidative damage. $J$. Physiol. Biomed. Sci., 24(2): 28-33.

44. Majekodunmi, S.O., Oyagbemi, A.A. and Odeku, O.A. (2014) Ameliorative effects of the ethanolic seed extract of Mucuna pruriens on alloxan induced biochemical alteration in male Wistar rats. Pharmacologia, 5(5): 177-183.

45. Adepoju, G.K.A. and Odubena, O.O. (2009) Effect of Mucuna pruriens on some haematological and biochemical parameters. J. Med. Plants Res., 3(2): 73-76.

46. Obogwu, M.B., Akindele, A.J. and Adeyemi, O.O. (2014) Hepatoprotective and in vivo antioxidant activities of the hydroethanolic leaf extract of Mucuna pruriens (Fabaceae) in antitubercular drugs and alcohol models. Chin. J. Nat. Med., 12(4): 273-283.

47. Fung, S.Y., Tan, N.H. and Sim, S.M. (2010) Protective effects of Mucuna pruriens seed extract pretreatment against cardiovascular and respiratory depressant effects of Calloselasma rhodostoma (Malayan pit viper) venom in rats. Trop. Biomed., 27(3): 366-372.

48. Sanghamitra, S., Hazra, J. and Upadhyay, S.N. (2008) Arsenic induced toxicity on testicular tissue of mice. Indian. J. Physiol. Pharmacol., 52(1): 84-90.

49. Waring, W.S. (2012) Novel acetylcysteine regimens for treatment of paracetamol overdose. Ther. Adv. Drug Saf., 3(6): 305-315.

50. Krishna, A.B., Manikyam, H.K., Sharma, V.K. and Sharma, N. (2016) Acute oral toxicity study in rats with Mucuna pruriens seed extract. Asian J. Plant Sci. Res., 6(2): 1-5.

51. Rai, K.S., Murthy, K.D., Karanth, K.S. and Rao, M.S. (2001) Clitoria ternatea (Linn) root extract treatment during growth spurt period enhances learning and memory in rats. Indian. J. Physiol. Pharmacol., 45(3): 305-313.

52. Bouayed, J., Rammal, H. and Soulimani, R. (2009) Oxidative stress and anxiety: Relationship and cellular pathways. Oxid. Med. Cell. Longev., 2(2): 63-67.

53. Rai, A., Maurya, S., Khare, P., Srivastava, A. and Bandyopadhyay, S. (2010) Characterization of developmental neurotoxicity of $\mathrm{As}, \mathrm{Cd}$, and $\mathrm{Pb}$ mixture: Synergistic action of metal mixture in glial and neuronal functions. Toxicol. Sci., 118(2): 586-601.

54. Sun, W., Jin, Y. and Sun, G. (2010) Prenatal and early life arsenic exposure induced oxidative damage and altered activities and mRNA expressions of neurotransmitter metabolic enzymes in offspring rat brain. J. Biochem. Mol. Toxicol., 24(6): 368-378.

55. Sun, H., Yang, Y. and Shao, H. (2017) Sodium arsenite-induced learning and memory impairment is associated with endoplasmic reticulum stress-mediated apoptosis in rat hippocampus. Front. Mol. Neurosci., 10: 286.

56. Luo, J.H., Qiu, Z.Q., Shu, W.Q., Zhang, Y.Y., Zhang, L. and Chen, J.A. (2009) Effects of arsenic exposure from drinking water on spatial memory, ultra-structures and NMDAR gene expression of hippocampus in rats. Toxicol. Lett., 184(2): 121-125.

57. Zhang, Y., Duan, X., Li, J., Zhao, S., Li, W. and Zhao, L, $\mathrm{Li}, \mathrm{B}$. (2016) Inorganic arsenic induces NRF2-regulated antioxidant defenses in both cerebral cortex and hippocampus in vivo. Neurochem. Res., 41(8): 2119-2128.

58. Tolins, M., Ruchirawat, M. and Landrigan, P. (2014) The developmental neurotoxicity of arsenic: Cognitive and behavioral consequences of early life exposure. Ann. Glob. Health, 80(4): 303-314.

59. Shen, S., Li, X.F., Cullen, W.R., Weinfeld, M. and Le, X.C. (2013) Arsenic binding to proteins. Chem. Rev., 113(10): 7769-7792.

60. Massaad, C.A. and Klann, E. (2011) Reactive oxygen species in the regulation of synaptic plasticity and memory. Antioxid. Redox. Signal., 14(10): 2013-2054.

61. Tavarekere, N. and Desiraju, T. (1994) Effects on operant learning and brain acetylcholine esterase activity in rats following chronic inorganic arsenic intake. Hum. Exp. Toxicol., 13(5): 353-356.

62. Yen, C.C., Ho, T.J., Wu, C.C., Chang, C.F., Su, C.C. and Chen, Y.W. (2011) Inorganic arsenic causes cell apoptosis in mouse cerebrum through an oxidative stress-regulated signaling pathway. Arch. Toxicol., 85(6): 565-575.

63. Flora, S.J., Bhatt, K. and Mehta, A. (2009) Arsenic moiety in gallium arsenide is responsible for neuronal apoptosis and behavioral alterations in rats. Toxicol. Appl. Pharmacol., 240(2): 236-244.

64. Lu, T.H., Tseng, T.J., Su, C.C., Tang, F.C., Yen, C.C., Liu, Y.Y., Yang, C.Y., Wu, C.C., Chen, K.L., Hung, D.Z. and Chen, Y.W. (2014) Arsenic induces reactive oxygen species-caused neuronal cell apoptosis through JNK/ERKmediated mitochondria-dependent and GRP 78/CHOPregulated pathways. Toxicol. Lett., 224(1): 130-140.

65. Luz, A.L., Godebo, T.R. and Bhatt D.P. (2016) Arsenite uncouples mitochondrial respiration and induces a warburg-like effect in Caenorhabditis elegans. Toxicol. Sci., 152(1): 349-362.

66. Ramos, O., Carrizales, L. and Yáñez, L. (1995) Arsenic increased lipid peroxidation in rat tissues by mechanism independent of glutathione levels. Environ. Health. Perspect., 103(Suppl 1): 85-88.

67. Peters, B.A., Hall, M.N. and Liu, X. (2014) Creatinine, arsenic metabolism, and renal function in an arsenic-exposed population in Bangladesh. PLoS One, 9(12): e113760.

68. Weidemann, D., Kuo, C.C., Navas-Acien, A., Abraham, A.G., Weaver, V. and Fadrowski, J. (2015) Association of arsenic with kidney function in adolescents and young adults: Results from the national health and nutrition examination survey 2009-2012. Environ. Res., 140: 317-324

69. Gora, R.H., Kerketta, P. and Baxla, S.L. (2014) Ameliorative effect of Tephrosia purpurea in arsenic-induced nephrotoxicity in rats. Toxicol. Int., 21(1): 78-83.

70. Rao, C.V., Pal, S., Mohammed, A., Farooqui, M., Doescher, M.P. and Asch, A.S. (2017) Biological effects and epidemiological consequences of arsenic exposure, and reagents that can ameliorate arsenic damage in vivo. Oncotarget, 8(34): 57605-57621.

71. Mershiba, S.D., Dassprakash, M.V. and Saraswathy, S.D. (2013) Protective effect of naringenin on hepatic and renal dysfunction and oxidative stress in arsenic intoxicated rats. Mol. Biol. Rep., 40(5): 3681-3691.

72. Poornachandra, M.N., Salma, K., Shivananda, B.G. and Shivananda, T.N. (2005) Mucuna pruriens (L.) DC a novel drug for learning and memory retrieval. J. Food Agric. Environ., 3(3-4): 644.

73. David, A.V.A., Arulmoli, R. and Parasuraman, S. (2016) Overviews of biological importance of quercetin: A bioactive flavonoid. Pharmacogn. Rev., 10(20): 84-89.

74. Rai, S.N., Birla, H. and Singh, S.S. (2017) Mucuna pruriens 
protects against MPTP intoxicated neuroinflammation in Parkinson's disease through NF- $\mathrm{kB} / \mathrm{pAKT}$ signaling pathways. Front. Aging Neurosci., 9: 421.

75. Kumar, S. and Pandey, A.K. (2013) Chemistry and biological activities of flavonoids: An overview. Sci. World J., 2013: Article ID 162750.

76. Suresh, S. and Prakash, S. (2011) Effect of Mucuna pruriens (Linn.) on oxidative stress-induced structural alteration of corpus cavernosum in streptozotocin-induced diabetic rat. J. Sex. Med., 8(7): 1943-1956.

77. Smedley, P.L. and Kinniburgh, D.G. (2002). A review of the source, behavior and distribution of arsenic in natural waters. Appl. Geochem., 17(5): 517-568.

78. McCarty, K.M., Hanh, H.T. and Kim, K.W. (2011) Arsenic geochemistry and human health in South East Asia. Rev. Environ. Health, 26(1): 71-78.

$* * * * * * * *$ 